\title{
The Mode of Action of Thyroid Stimulator (TSH and LATS)
}

\author{
Yukio OCHI \\ Second Department of Medicine, Kyoto Prefectural University \\ of Medicine, Kyoto Japan
}

TSH stimulates the secretion and synthesis of thyroid hormone, and also stimulates many metabolic pathways i.e, salt and water, carbohydrate, phosphorus and phospholipid, nucleic acid, amino acid and protein metabolism. Evidence has been accumulated that LATS causes a prolong effect on the thyroid and LATS differs in several respects from TSH. Until now the precise role of TSH and LATS at cellular level has not been known and the mode of action of two substances is not clear.

In this paper, the metabolic effects of TSH and LATS on the thyroid were examined extensively using both in vitro and in vivo systems. The incorporation of ${ }^{32} \mathrm{P}$ into the thyroid gland after a single injection of LATS and TSH was increased about 2 fold in the thyroxine treated mice. Also specific activities of RNA and phospholipid in the gland were increased remarkably. Experiments using ${ }^{3} \mathrm{H}$-uridine, TSH and LATS increased the incorporated radioactivity per RNA.

A single injection of TSH or LATS into mice falied to stimulate the incorporation of ${ }^{3} \mathrm{H}$-leucine into thyroidal protein. While the continuous injection of LATS for 5 days caused increased thyroid weight, augmented protein content and increased incorporation of ${ }^{3} \mathrm{H}$-leucine. Also the specific activity of incorporated radioactivity per $\mathrm{mg}$ thyroid protein was significantly increased. Treatment with LATS or TSH for 8 days produced marked goiter formation accompanied by a high $\mathrm{I}^{131}$ thyroidal uptake. LATS stimulates protein synthesis in the gland, as does TSH.

Using McKenzie's method, cyclic 3' 5' AMP (C 3' 5' AMP) and Dibutyryl cycilic 3' $5^{\prime}$ AMP (D.G 3' 5' AMP) were found to increase thyroid hormone release from mouse thyroid in vivo. Other adenine nuclectides were also active. Simultaneous injection of theophylline and caffeine with C 3' 5' AMP and D.C 3' 5' AMP augmented the stimulatory effect of these adenine nucleotides on hormone release, although theophylline or caffeine had only a slight effect alone. No effect was obtained by the injection of $\mathrm{NaF}$ with D.G 3' 5' AMP. These adenine nucleotides have no enhancing action on hormone release from mouse thyroids during in vitro incubations, and no stimulatory effects were obtained by the nucleotides on the hydrolysis of thyroglobulin in mouse thyroid homogenates. These adenine nucleotides appeared to have no direct action on the enzyme participating in the breakdown of thyroglobulin.

According to Pastan's method, the effect of TSH on cyclase activity was determined using beef and rabbit thyroid homogenate, but the increase of cyclic AMP synthesis from ${ }^{3} \mathrm{H}$-ATP (or ${ }^{14} \mathrm{C}$-ATP) was not obtained by the large doses of TSH. Similarly also LATS 
haven't any stimulating action on adenyl cyclase activity. NaF did not elevate adenyl cyclase activity, but inhibited ATP destruction by the inhibition of ATPase. Theophylline inhibited cyclic AMP destruction significantly. Using beef thyroid slices, ${ }^{3} \mathrm{H}$-adenine was preincubated for $1 \mathrm{hr}$ and then TSH (Armour or NIH) or LATS was incubated for 30 min. with theophylline or $\mathrm{NaF}$. The incorporated radioactivity into cyclic AMP in whole thyroid slice was examined. TSH and LATS similarly stimulated the incorporation of ${ }^{3} \mathrm{H}$-adenine into cyclic AMP in beef thyroid slice, especially in the presence of theophylline. However, the stimulatory effect of $\mathrm{NaF}$ on cyclic AMP formation was very slight.

Both TSH and LATS elevated cyclic AMP levels in the gland, however it may be some of effects of both these thyroid stimulator. It is possible that TSH and LATS have similar stimulating action on various metabolism in the thyroid.

(See pp. 625 630) 


\title{
シンポジウム $\mathrm{I} \quad$ ホルモンの作用機序 \\ 3. 甲状腺刺激ホルモン（TSH 及び LATS）の作用機序
}

\author{
京都府立医科大学丸本内科 \\ 越智幸男, 八谷孝 \\ 阿部勢 津 子, 塩 見勝 彦
}

緒 論

TSH は甲状腺ホルモン合成分必を促がすと同時に, 甲状腺内の諸物質代謝を促進さす。代謝面では腺内 の水, 塩類代謝, 酸素消費, ヨード代謝, 糖, 燐及び燐脂質, 更に蛋白及び核酸代謝等を促進する. てれら の多彩な代謝促進の primary step が如何なる機序によって行なわれるかに関しては，統一した見解はない． しかし, 細胞膜の透過性の変化や, 細胞内の特定の醭素系への影響又は, 核酸及び蛋白合成などという問題 について研究がなされている.

近年甲状腺機能元進症患者血中に, TSH と異なる Long Acting Thyroid Stimulator (LATS) が存在 するととが確認され，ての LATSはTSH よりも甲状腺を長時間刺激するとと，また免疫学的にも TSH と異なる物質とされている ${ }^{122)}$ (Table 1). 今回は現在までに発表されている TSH と LATS の甲状腺一 の作用点を比較検討しながら私達の研究結果を述べてみたい.

Table 1 Comparison of TSH and LATS

\begin{tabular}{|c|c|c|}
\hline Characteristic & $\mathrm{TSH}$ & LATS \\
\hline Response by McKenzie method & $2 \mathrm{hr}>8 \mathrm{hr}$ & $2 \mathrm{hr}<8 \mathrm{hr}$ \\
\hline Biologic half life & & \\
\hline Rat & $<20 \min$ & $7.5 \mathrm{hr}$ \\
\hline Human & $30 \mathrm{~min}$ & 25 days \\
\hline \multicolumn{3}{|l|}{ Heat stability } \\
\hline $56^{\circ} \mathrm{C}$ for $30 \mathrm{~min}$ & No loss & No loss \\
\hline $70^{\circ} \mathrm{C}$ for $10 \mathrm{~min}$ & About $55 \%$ lost & Almost completely lost \\
\hline Sedimentation constant & $4 \mathrm{~S}(\mathrm{mw} 20,000)$ & $7 \mathrm{~S}(\mathrm{mw} \quad 160,000)$ \\
\hline Neutralization with antibody & Anti-TSH antibody & Anti-IgG antibody \\
\hline Kidney passage & $+?$ & $-?$ \\
\hline Placenta passage & - & + \\
\hline Thyroxine suppression & + & - \\
\hline Bates extraction & + & - \\
\hline Electrophoresis & No single spot & $\gamma$-Globulin fraction \\
\hline Stimulatory response & All animals & Mammalian species \\
\hline
\end{tabular}

\section{（A）甲状腺刺激物質の諸代謝促進作用}

（1）糖代謝に及ぼす影響

TSH は甲状腺内の Hexose Monophosphate Pathway (HMP) を特異的に促進する. ゆえに糖代謝に関 
与する腺内の醉素活性に及ぼすTSH の影響を観察してみた。すなわち G-6-PDH 及び 6-PGDH 等へのTSH の影響をラットを用いて観察すると，TSH $10 \mathrm{U}$ 投与 24 時間以内では，本酵素活性上昇は殆んど認められ ない.しかし, propylthiouracil の様な抗甲状腺剤の連続投与によつて, 甲状腺重量增加か諗められると酵 素活性は著明に上昇した．TSH により HMP が促進されると G-6-PDH や 6-PGDH の作用によつて TPNH の生成増加が起り，ての TPNH が iodotyrosine の脱ヨード醉素の補醅素となつて作用するてと が推定される ${ }^{3)}$.

ラット甲状腺内の脱ヨード酵素活性に及ぼすTSH の影響を観察すると, TSH 2 単位 1 回注射 6 時間後 までは僅かに活性上昇が認められるのみである。一方本酵素活性測定時に甲状腺ホモジネート内に TPNH を多量に加えると，醰素活性は約100倍も増加した。乙の様な TPNH 飽和条件下での醳素活性を測定する と，酵素活性の著增が起るが，TSH 処理の有無は特に醉素活性に影響を及ばさなかつた，本酵素活性に及 ぼす TSH の速効性の促進反応は, cofactor の利用増大によるものであつて, 酵素蛋白自体の増量は二次 的であると推定される゙).

\section{（2）燐及ひ燐脂質代謝に及ぼす影響}

TSH により $\mathrm{P}^{32}$ の腺内とり込みと phospholipid への転入促進作用が認められるという報告は多い.

LATS も TSH と同様に in vitro で phospholipid 代謝促進作用があるてとが報告されている. In vivo でも，LATS は TSH と同様な促進作用がある. すなわちマウスに TSH $80 \mathrm{mu}$ 及び LATS-IgG 60mg 注射 4 時間後に $\mathrm{P}^{32}$ を投与し, 更に 4 時間後における単位 phospholipid の放射能の転入は増加するてと を確誌した5).

\section{（3）核酸代謝に及ぼす影䋨}

TSH によつて甲状腺内 RNA 量の著増が起るという報告は多い. LATS も TSH と同様に核酸代謝促 進作用がある. すなわち in vivo そて, TSH 80mu 及び LATS-IgG 60mg 投与 4 時間後に $\mathrm{H}^{3}$-uridine を注射し，更に 4 時間後のマウス甲状腺内への $\mathrm{H}^{3}$-uridine の転入を観察すると，甲状腺全体でも単位 RNA 当りでも増大が認められだ).

\section{（4）アミノ酸及び蛋白代謝に及ぼす影響}

TSH 投与によつて, 甲状腺切片への諸種アミノ酸転入が促進をうけると報告されている. In vivoにて, TSH 及び LATS のマウス甲状腺内蛋白代謝を観察すると, TSH 80mu., LATS-IgG 60mg の連続投与. によつて, 甲状腺重量増加が 5 日間で約 2 倍になる。 ての場合 $\mathrm{H}^{3}$-leucine の転入は単位蛋白当りでも著明 であつた。しかし同量の TSH 及び LATS の1回注射の場合には腺内への $\mathrm{H}^{3}$-leucine の転入促進は殆ん ど慧められなかつだ).

\section{（5）ヨード代謝に及ぼす影響}

LATS は TSH に比べて甲状腺からの $\mathrm{T}_{4}$ 分泌を長時間促進し, 更に甲状腺 $\mathrm{I}^{131}$ uptake をも促進する. すなわち LATS 又は TSH を 8 日間注射して, 甲状腺重量がそれぞれ 2 倍及び1.5倍以上増加した時に, $I^{131}$ uptake もそれぞれ対照の数倍に増加しだ).

\section{(B) TSH 及ひ LATS の活性と分子量}

TSH とLATS は上述の様に斘状腺への作用はほぼ同じである. 現在までに知られている TSH と LATS の円状脉への作用の差違としては，TSH はヒョコの甲状腺を刺激するが，LATS は全然刺激しな いととである. しかも，分子量16万の LATS papain 又は pepsin 更にてれらに cysteine を加えて処 理して得た分画，すなわち分子量 10 万及び 5 万の小分子はマウスの甲状腺刺激作用を持つているが，ヒヨコ の甲状腺を刺激しなかつた7). 現在までのとてろ TSH ゃ LATS は甲状腺細胞膜に touch したのみで， 甲状腺への多彩な刺激反応を惹起するのか，細胞膜を通過して核まで到達して作用するのがは不明である.

(C) 甲状腺刺激物質ट Cyclic AMP

甲状腺刺激物質により促進をうける甲状腺内の代謝のうち, Actinomycin D p Puromycin で直ちに抑 制されないものとして、ヨード代謝, 糖代謝及び燐代謝等がある.ゆえに甲状腺刺激物質の甲状腺への first 
step は新しい蛋白及び核酸合成を特に必要としないものと推定される.

最近, peptide hormone の標的藏器への作用機序の first step として cyclc 3',5'-AMP 説が提唱されて いる ${ }^{8}$. Cyclic AMP が TSH と同様な甲状腺内の代謝を促進するという報告がある. Cyclic AMPょりも 一層細胞膜透過性の高い dibutyryl cyclic AMP は in vivo および in vitro で甲状腺に TSH が作 用したのと同様な変化, すなわち形態学的変化, 糖 代謝, 燐及び燐脂質代謝等を促進した ${ }^{9) \sim 12)}$.

また Pastan らは TSH が甲状腺 homogenate 中で cyclic AMP の増量を起したと報告している 13). Gilman, Rall らは甲状腺切片レベルでの cyclic AMP 生成促進が TSH で起るととを報告した ${ }^{14)}$.

(1) Cyclic AMP の甲状腺刺激作用

1. in vivo の実験

Mckenzie 法を用いて観察すると thyroxine 分 泌は AMP, ADP, ATP, cyclic 3'5'-AMP, 及び dibutyryl cyclic $3^{\prime} 5^{\prime}$-AMP 等の adenine nucleotide $5 \mathrm{mg}$ で促進された. しかしてれらの反応は TSH 0.5mu 程度であつた. 一方 GTP, UTP, CTP, Cyclic 2'3'-AMP, 3'-AMP, 2'-AMP, adenosine 及 び adenine 等では促進されなかつた (Fig. 1).

Theophylline p caffeine 等の methyl xanthine. 剤は, 単独では thyroxine 分泌は促進しないが,

Fig. 1.

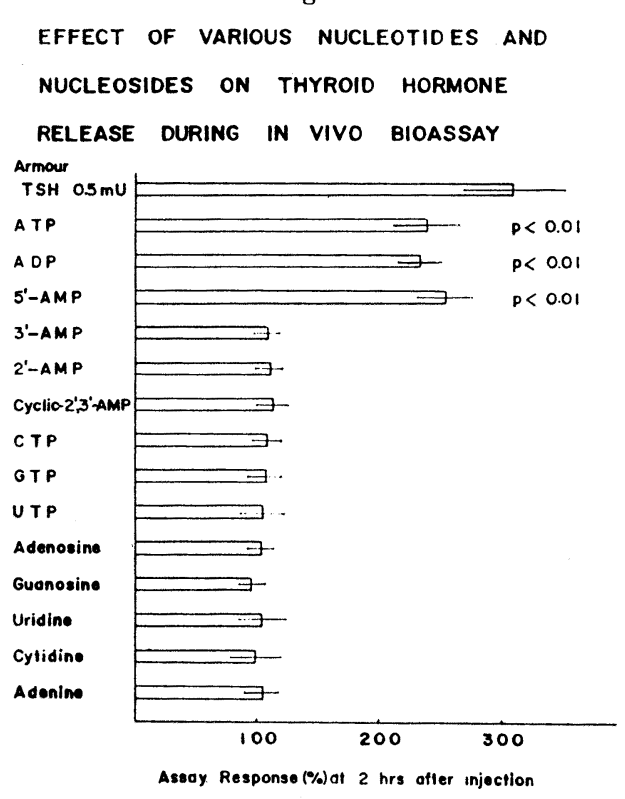

Each material was injected $5 \mathrm{mg}$.

Fig. 2. Effect of methylxanthine compounds or $\mathrm{NaF}$ alone or given simultaneously with Dibutyryl-3', 5'-AMP (D, C,-3', 5'-AMP) on thyroid hormone release in McKenzie method. Theophylline (TH), Caffeine (CF), or NaF was injected i.v. 1mg. per mouse. D.C.-3', 5'-AMP (5mg.) was injected simultaneously with theophylline or $\mathrm{NaF}$.

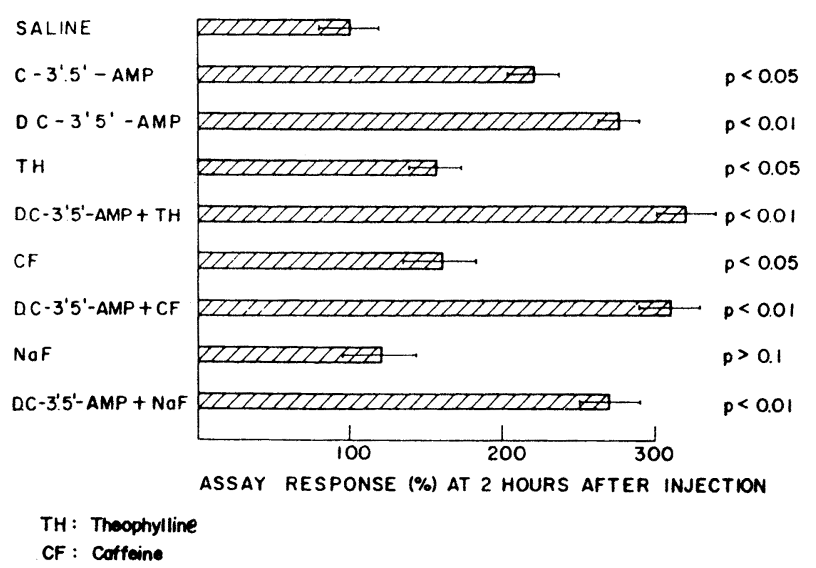


Cyclic AMP や dibutyryl AMP の作用をわずか に增強した. NaF は cyclic AMP や dibutyryl cyclic AMP の作用に影響を与えなかつた ${ }^{15)}$ (Fig. 2).

口. in vitro の実験

$1^{125}$ でラベルされた甲状腺を直接 cyclic AMP や dibutyryl cyclic AMP, その他の adenine nucleotide と保生しても, 多量の thyroglobulin が 短時間に保生液中に漏出するため游離の thyroxine 増加を認めなかつた. 放射性ヨードでラベル された甲状腺を homogenateし，てれに種々の adenine nucleotide を添加しても, thyroglobulin の加水分解の促進を諗めなかつた ${ }^{15)}$.

(2) Cyclase に及ぼす影響

\section{イ、ホモジネートを用いる実験}

牛甲状腺ホモジネートを用いて，腺内の cyclase 活性を $\mathrm{H}^{3}$-ATP を基質として検討した. 実験条件 はほぼ Pastan らの方法に準じて行なつた ${ }^{13)}$.しか し Pastan の報告した様な TSH による cyclic AMP 生成増大を認めなかつた。 ての点に関しては 更に検討の予定である.

また NaF の添加は Cyclic AMP 生成に影響を 及ばさなかつた。一方 theophylline によつては著 明な Cyclic AMP 生成増大が認められた (Fig. 3).
Fig. 3.

EFFECT OF TSH, THEOPHYLLINE AND NaF ON ADENYL CYCLASE ACTIVITY IN BEEF THYROID HOMOGENATE

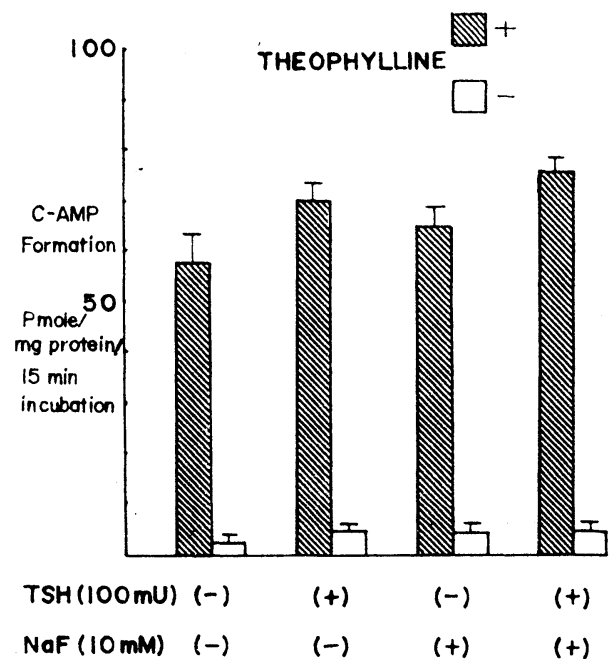

Reaction mixture of $0.06 \mathrm{ml}$ contained ; ATP $0.65 \mathrm{mM}, 2 \times 10^{5} \mathrm{cpm}$ of ${ }^{3} \mathrm{H}$ 8-ATP, theophylline $8 \mathrm{mM}, \mathrm{MgCl}_{2}$ $2 \mathrm{mM}$, tris- $\mathrm{HCl} 21 \mathrm{mM}, 0.08 \%$ bovine albumin and $2 \mathrm{mg}$ of thyroid homogenate. C-AMP (Cyclic AMP)

しかしての theophylline による生成増大は, phosphodiesterase の活性抑制によるもので, cyclase 活性 促進によるものではない.

Fig. 4.

EFFECT OF TSH, LATS AND NaF ON H3-CYCLIC-3',5-AMP

HYDROLYSIS IN BEEF THYROID HOMOGENATE

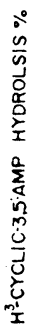

政

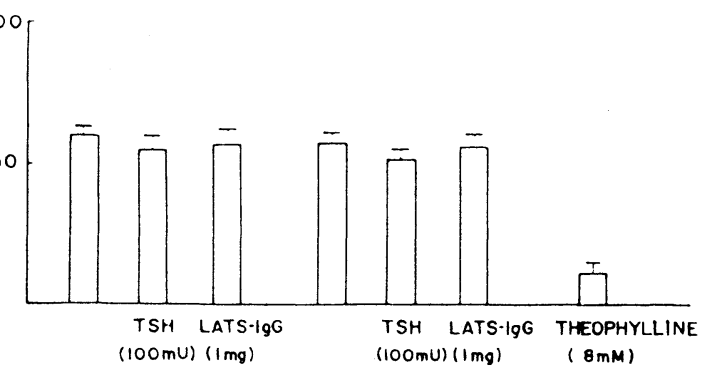

$\operatorname{NoF}(10 \mathrm{mM})(+) \quad(+) \quad(+) \quad(-) \quad(-) \quad(-)$

LATS-IgG (1mg) produced a 500\%" response in McKenzie method.

Incubation conditions were identical to those deseribed in Fig. 3. except that ATP was omitted, and each reaction mixture contained 100 picomoles ${ }^{3} \mathrm{H}$-cyclic-3', 5'-AMP. 
なぜならば牛甲状腺 homogenate で $\mathrm{H}^{3}$-cyclic AMP の分解に関与する phosphodiesterase 活性を theophylline は著明に抑制したからである(Fig. 4). また LATS も甲状腺 homogenate を用いての実 験で, cyclase 活性及び cyclic AMP 分解に何ら影 響を及ぼさなかつた。

また甲状腺 homogenate を用い，基質 ATP の 分解に及ぼす theophylline, NaF 及び TSH の影 響を観察した. Theophyllineゃ TSH は何らの影 響をも認めなかつたが， NaF は ATP の分解を著 明に抑制した。これらのことより $\mathrm{NaF}$ は cyclase 活性には影響を及ぼさないが，ATPase 活性を抑制 するものと推定される (Fig. 5).

\section{口. 切片を用いる実験}

$\mathrm{H}^{3}$-adenine を用いて，牛甲状腺切片中の cyclic AMP への転入促進を TSH 及び LATS で検討し た. 牛甲状腺切片 $100 \mathrm{mg}$ と, $\mathrm{H}^{3}$-adenine を 1 時問 preincubation したのち，TSH $100 \mathrm{mu}$ 及び LATSIgG $16 \mathrm{mg}$ を添加後30分保生した.

甲状腺切片 $100 \mathrm{mg}$ 中の Cyclic AMP への $\mathrm{H}^{3}$ adenine の転入を示すと，保生液中に theophylline がある場合には， $\mathrm{H}^{3}$-adenine の cyclic AMP への 転入促進が認められた。しかも，NaF の添加は cyclic AMP をわずかに増量させた. TSH は Armour， NIH 共に著明に cyclic AMP への転入増大を起した。この場合 theophylline は更に著明な cyclic AMP 生成増加を起した. LATS は NaF 及び theophylline 単独の場合にも増加を認めたが, NaF と theophylline を同時に添加した場合にも，cyclic AMP への著明な転入増加を起した (Fig.6).

Fig. 6.

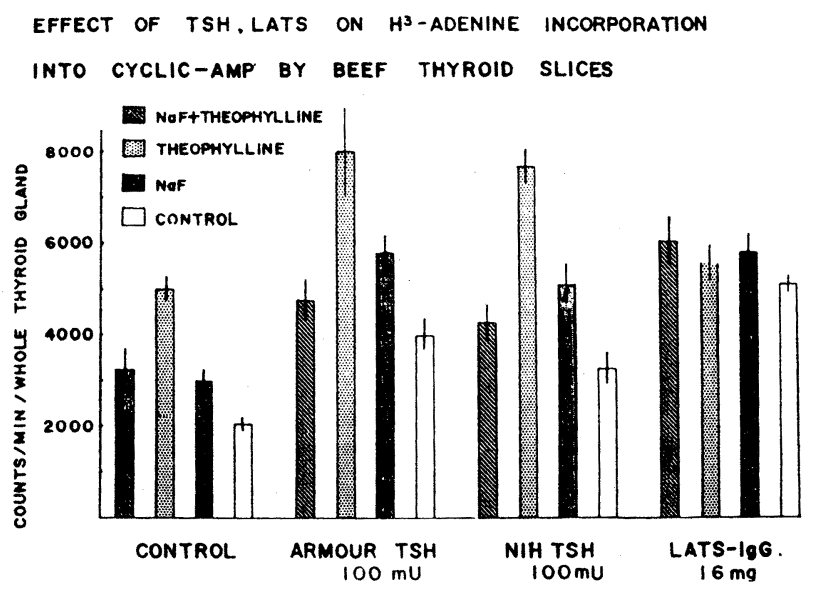

Reaction conditions ; Using thyroid slices, ${ }^{3} \mathrm{H}$-adenine $100 \mu \mathrm{c} / 2 \mu \mathrm{g}$ was preincubated for $1 \mathrm{hr}$. and then TSH, or LATS was incubated in $0.5 \mathrm{ml}$ of Krebs Ringer phosphate for $30 \mathrm{~min}$. with theophylline $8 \mathrm{mM}$ or $\mathrm{NaF} 10 \mathrm{mM}$. 
TSH と LATS はほほ同様な甲状腺刺激作用をもつている。 てれらの甲状腺内諸代謝への刺激効果は Cyclic AMP によつても認められた。 TSH と LATS は共に甲状腺切片で Cyclase 活性を上昇させ，Cyclic AMP 生成を增加させた。

しかし Cyclic AMP では TSH や LATS による著明な甲状腺刺激反応を完全には再現出来なかつた。 これらの両刺激物質の甲状腺への first step が cyclic AMP の生成によるものかいなかは更に今後検討す べき問題である.

口演を終るにあたり，発表の機会を与えて下さいました本会会頭西川教授，司会をして載きました山村， 宇井教授並びに終始御指導をたまわりました丸本教授に深謝致します。

\section{文献}

1) McKENZIE, J.M. : Recent Progr Hormon Res. 23 : 1, (1967)

2) OCHI, Y. and L.J. DeGROOT : New Eng. J. Med., 278 : 718, (1968)

3）越智幸男, 丸本 晋, 横田 敬, 八谷 孝, 阿部勢津子：ホルモンと臨床, $14: 327$, (1966).

4）越智幸男, 横田 敬, 丸本 晋：日本内分泌 学会雑誌, $41: 804,(1965)$

5) OGHI, Y. and L.J. DeGROOT : Biochem. Biophys. Acta., 170 : 198, (1968)

6) OCHI, Y. and L.J. DeGROOT : Endocrinology $85: 344$, (1969) 